\title{
The Theme of Infanticide in Selected Anglo-American Literature
}

\author{
${ }^{1}$ Dr Tanu Gupta, ${ }^{2}$ Ms Ramandeep Mahal, \\ I'Associate Professor, Department of Humanities and Social Sciences, Maharishi Markandeshwar University \\ Mullana (Ambala)) \\ ${ }^{2}$ Research Scholar, Ph.D in English, Department of Humanities and Social Sciences, Maharishi \\ Markandeshwar University Mullana (Ambala))
}

\begin{abstract}
The theme of infanticide has been seen as a prominant factor in all these works. I have applied this theme in my five works I have studied. These works cover the anglo american literature from 1859 to 1987.the works are George Eliot's Adam Bede,Eugene O'Neill's Desire Under the Elms,Edward Albee's The American Dream,Sam Shepard's The Buried Child and Toni Morrison's Beloved. The causes for the murder of infant range from shame of being shunned by the society, anger, lunacy, protection etc. The author's backgrounds also reveal a world of deranged families, the search for love which made them write the following works.
\end{abstract}

Keywords : infanticide, shame, lunacy, love, infant, murder

Infanticide is a felony defined as, the murder of a new born by its mother, possibly abetted by others. This definition of this crime particularly arose in Europe in the seventeenth century because it was virtually impossible to prove guilt under the existing laws, often common law, for murder. A mother was the only witness to what occurred, and the state could not easily show that the child had been still born or murdered in seventeenth century England. Single women who killed their newborns were believed to have acted to hide their shame. They were prosecuted under the 1624 Concealment Law and punished by death. This harsh response eventually evolved into a more humane and sympathetic one, as shown by the increasing number of acquittals in the late eighteenth century and by the sharp drop of prosecutions in the late nineteenth century. Then in, 1922, England passed the Infanticide Act, amended in 1938, which provided that a mother who killed her child would be prosecuted for manslaughter not murder. Today great majority of women prosecuted under English infanticide laws do not serve prison sentences, but instead receive counseling.

Literary works provide a great opportunity through the use of several narrative strategies; to slow society's rush to judge such mothers. George Eliot's Adam Bede (1859), Eugene O'Neill's Desire under the Elms (1924), Edward Albee's The American Dream (1961), Sam Shepard's Buried Child (1978) and Tony Morrison's Beloved (1987). These works offer insight into the complex and contradictory motives of women who kill newborns, and thus provide a model for judgments that are more humane and authentic, judgments that give recognition to a story we typically would rather suppress.

\section{George Eliot's Adam Bede}

George Eliot is the pen name of Mary Ann Evans. As a woman novelist in the Victorian age Mary Ann Evans realized the limitation of her own sex and hence changed her name. A woman as an author was considered unprofessional. George Eliot's career as a journalist and reviewer exposed her to the latest social and scientific theories. According to Henry, "consequently she had an extraordinary broad grasp of historical, philosophical and literary issues" (138). Eliot's goal was to integrate philosophical and aesthetic methods in fiction to inspire moral and social action. George Eliot was not a typical woman of the Victorian era. She lived openly with a man who was not her husband despite her familial and social disapproval. She was also ambitious and one of the greatest authors of her time. Yet she punishes her female characters in her novels who try to pursue their ambitions. Adam Bede is her second full length novel which was published in 1859. The journals about George Eliot edited by Gordon S. Haight suggest that Adam Bede was based on a story Eliot had heard from her Aunt, Elizabeth Evans, a Methodist minister who is acknowledged to have been the model for Dinah in the novel. Also to be used in establishing the biographical facts of Eliot's life and the implications that had on her fiction are Rosemarie Bodenheimer's The Real Life of Mary Ann Evans: George Eliot, Her Letters and Fiction (1994), and Rosemary Ashton's George Eliot: A Life (1996). Adam Bede is a third person narrative written from the point of view of the omniscient narrator. The story is set in the fictional quiet rural community of Hayslope in Loamshire at the end of the eighteenth century. The plot is based on a real confession of a child murder to a Methodist preacher Elizabeth Evans, George Eliot's aunt. The character of Dinah Morris is based on the preacher while Hetty represents the girl in the prison. As the name suggests the main protagonist of the novel is male. Adam Bede, like Christ is a carpenter and the description which follows asserts his superiority. 
The focus of study is Hetty Sorrel whose role is secondary but deals with infanticide. She is not introduced until the chapter seven in the novel. Hetty is a naïve country girl who falls pregnant after a man of a socially higher class Captain Arthur Donnithorne who thoughtlessly seduces her. She loves finery and is vain about her looks. Hetty throughout the novel is shown as an indifferent character. Hetty's flaw is created by her own self deception. Before her first appearance, her character has already been established through the comments of other characters, beginning with Dinah Morris. Dinah Morris refuses to leave Hayslope as her "heart yearns over ... that poor wandering lamb Hetty Sorrel." (34) When Captain Arthur Donnithorne abandons Hetty, she realizes that she won't be able to conceal her condition. Unable to bear the burden of an illegimate child Hetty decides to leave the child to die in the woods, though its cries haunt her every time. Later she is imprisoned for the murder of the child.

\section{Eugene O Neill's Desire Under The Elms}

American playwright Eugene O'Neill usually deals with tragic plays. He is a prolific playwright and he has written many plays during his lifetime. According to Bogard, "He has written sixty two plays out of which eleven were destroyed." (12) He has taken drama as a serious endeavor. He singlehandedly transformed American Theatre in the early twentieth century. His father, James O' Neill was a touring actor, his mother Elle was worshipped by Eugene. Given morphine at the time of Eugene's birth, she spent rest of her life as an addict. From the age of seven to thirteen he attended Catholic schools, then four years at a non-sectarian preparatory school, followed by one year 1906-1907 at Princeton University. After expulsion from Princeton he led a restless, wandering life for several years, working at various occupations. He never held a job long. His first twenty four years included alcohol abuse so severe that he was near death. He had brief marriage between visits to brothels. Hospitalized for tuberculosis, he decided to straighten up and devote himself to writing plays. The play Desire under the Elms is an ancient play written by Eugene O'Neill in 1924. The play opens in 1850, New England. Ephraim Cabot, the head of the family is a god fearing man. Having lost his first two wives, he returns to his farm with a third one, Abbie Putnam. She is received by his three sons, of whom two leave for California. The youngest son Eben stays in order to work at the farm. Eben yearns to be the sole owner of the farm, but his plan goes awry when his father gets a new bride. Eben is haunted by his lost mother, whose love he misses. Eben wants to avenge his father because of his father's betrayal of love for his dead mother. Eben intends to have a baby with Abbie so as to seize his mother's property from his father. However Abbie has her own plans, she uses her sexuality to seduce Eben and gives an heir to her husband and inherits the farm for her. They begin to have a sexual affair. Eben finds a lover and a mother figure in Abbie. A misunderstanding leads Eben to believe that Abbie's love is all false. To prove her love for Eben she murders her own child. Arnold Goldman has pointed out:

Abbie murders her and Eben's child to prove "her" love for him, to prove she did not want a child to steal the farm Eben has stolidly (and greedily) maintained was his by right. (48)

\section{Edward Albee's The American Dream}

Edward Albee belongs to the theatre of the Absurd. Absurd plays express an underlying anxiety that man drifts through an unexamined life in which routine and social conventions are used as a means of avoiding personal pain and isolation. As Albee once remarked, "anybody who doesn't carry a certain amount of existential angst with them throughout their lives is either dumb brute, or by chance insensitive. We must have it. We have to have it." (130) His plays, like those of his Absurd colleagues, are designed to alert their audiences to a deeply disharmonious human condition. Born in 1928, somewhere in Virginia, Albee was abandoned by his biological parents and adopted by Reed and Frances Albee. Frances was Reed's third wife and she was twenty three years younger than her husband. Albee's childhood was extremely comfortable and began attending theatre at the age of six and wrote Aliqueen, a three act sex farce, when he was twelve. Bigsby has remarked"Surrounded with material goods but perhaps deprived of love," he became an educational rebel" (250). After being dismissed from certain private and military schools. Albee entered The Chaote School in 1944. Although he performed there poorly, but he was happy. He continued writing poems, stories and wrote his first play The Schism and even a lengthy novel called The Flesh of the Unbelievers. After that he was enrolled in the Trinity College from where he was expelled due to his non-attending of courses and chapels. At the age of twenty Albee had a fight with his adoptive mother and according to Bottoms, "decisively walked out on his wealthy, adopted parents" (2). He moved to New York's Greenwich Village, where he held a variety of jobs. His first one act play to exhibit the child murder was The American Dream which was first performed in New York in 1961. In the play The American dream, the primary characters are Mommy and Daddy, a married couple living in an apartment. According to Kerr, "theirs is an "antiseptic family, whose teeth are obviously cleaned twice a year and whose souls were picked clean so long ago that no further brushing is necessary" (5). Mommy and Daddy exhibit no signs of love. They have been stripped of all genuine affection or mutual concern. The third member of the family is Grandma, Mommy's mother who lives with the couple. Rather than 
exhibiting care for her, the off spring expects the elderly woman "to earn her keep" and "take care of the house."(67) Once the plays characters are established, much of the rest of the play concerns Mommy and Daddy's adoption of a child that they term a "bumble of joy" (97). The story of Bumble is told by Grandma to Mrs. Barker who is a representative of the Bye Bye Adoption Agency who comes to call on the family. Unable to create and take care of a baby themselves, Mommy and Daddy decide to adopt one. The child did not satisfy the parent's ideal for a son. Instead of caring for the child they start to mistreat it and eventually kill it. Later in the play another visitor, The young man enters. He is a beautiful person, with a perfect profile and Grandma considers him, "The American Dream".

\section{Sam Shepard's Buried Child}

Sam Shepard, playwright and actor, has been a leader of the avante-garde in contemporary American theatre since his earliest work. Shepard's plays are difficult to categorize, but in general they blend images of the old west, fascination with pop culture - rock and roll, drugs and television - and bizarre family problems. Shepherd's father, was a bomber pilot in World War Two, and after the war his family moved from base to base. They eventually settled in a ranch in California and here Shephard developed love for animals. His father became an abusive alcoholic and after some serious confrontations with him, Sam left his agricultural studies at San Antonio Junior College at 19 to join a touring theatre group, the Bishop's Company. Later he was made a playwright in residence at the Magic Theatre in San Francisco. Before he was 30, Shepard had more than 30 plays produced in New York. Shepard repeatedly examines moral and spiritual starvation in his dramas. For decades his works have shocked, alienated and mesmerized audiences. Buried Child is undoubtly Shepard's most powerful plays. The play depicts an American family that violates civil, criminal and biblical laws. The play focuses on the characters of Dodge, Halie, Tildon and Bradley. The members of the family are either victims or accomplice to a murder. Dodge comes to represent the antithesis of the traditional $20^{\text {th }}$ century patriarch

\section{Dodge: I'm an invisible man! (68)}

Dodge is the only character in the play that never leaves the stage, which emphasizes his lack of role in the public life. Family secrets, such as incest and infanticide, have ruined his sense of masculinity. He insists that at one point this family was "well established" (123). His wife was pregnant as a result of incest between her and her son Tilden. The child marks a turning point for the fate of the family, and prompts a major shift in Dodge's sense of manhood by challenging his position of authority within the family. Dodge resolves to kill the baby boy who threatens his patriarchal power. However, after realizing his inability to control the action of his eldest son, Tilden and even the sexuality of his wife, Dodge realizes that he is utterly disempowered and he decides to imprison himself within his own house. Other sons include Bradley, whom Dodge doesn't give any importance, and denies that Bradley could even be his son. Then there is Ansel, who is dead and the other one who is mentioned as the "buried one". As Karpel remarks, "when all the members know the secret and know they all know, the secret serves to strengthen the boundary between the family and the outside world. In extreme cases, it may make alliances between family members and persons outside the family virtually impossible." (297)

\section{Toni Morrison's Beloved}

Toni Morrison has always excelled in creating her female characters. Her novels show a deep sense of bonding between the female characters. Morrison was born in Ohio and was the second to the four children born to her parents. Morrison's father told her numerous folktales of the black community, a method of storytelling that became a way which became a way of her writing. Morrison played a main role in bringing black literature into the mainstream. Beloved (1987) is Morrison's most sensitive novel till date. It deals with the forgotten era of slavery and the pathos of black slaves. The most striking element in the novel is the wrenching story of a black female slave, Sethe, who kills her own daughter to protect her from the horror of slavery. Slavery is harmful that dehumanizes men who lose their own identity. They become slaves to other men. In Beloved, Morrison takes the newspaper story of Margaret Garner who killed her two year daughter rather than have her sent back to slavery due to the fugitive slave law. Sethe is the heroine of the novel. She is a black slave, who lost her mother at a very young age. She was brought to Sweet Home Plantation as a slave where she marries Halle Suggs and bears four children from him. She suffers the most inhumane treatment at the plantation by the white masters. She is whipped mercilessly and milked like a cow. The whites according to Peach, ". . . sucked her lactating breasts." (109) Sethe is traumatized by the incident that she decides to run away from the plantation. She lands at her mother-in-law's place. To her horror she is soon traced and takes the most horrific step of killing her daughter to show resistance against slavery. The act of infanticide was due to the circumstances in which Sethe had to live and the brutality she had to endure as a slave in Sweet Home. She is imprisoned for seven years for the murder she committed and is later secluded by the society. 
George Eliot's Adam Bede tells the story of two ambitious women Dinah Morris and Hetty Sorrel. Though not related to each other both are found in the same home at the beginning of the novel. Both are completely opposite to each other. Dinah wants to preach and help the poor; on the other hand Hetty wants to marry a rich person, in order to avoid the working on the farm. At times Eliot characterizes Hetty as innocent and childlike, thereby eliciting sympathy for her, and at other times Eliot is critical of Hetty's vain, heartless behavior. According to Patricia Beer, "George Eliot has surely a real affection for her heroines, often perhaps, more than the readers can summon up. Yet she says dreadful things about them." (195) Hetty's childlike behavior causes her own downfall. For the murder of the child, she gets imprisoned. As the novel proceeds further we see that Hetty makes her sins lighter to bear by confessing her crime to Dinah. Hetty is a case of infanticide by an unwed mother trying to wipe out the shame of her accidental pregnancy. Due to Eliot's unconventional background she probably tried to project the social censure she faced as a woman through her female characters.

In the play Desire Under the Elms by Eugene O'Neill Abbie in the beginning of the play seems to be interested only in the materialistic things. Her main aim is to gain the farm with which she thinks she could have by providing an heir to Ephraim. However she finds her stepson attractive and seduces him. Eventually she falls in love with Eben who later finds out that she wanted the child only to become the heir of the farm. Failing to convince Eben that she loves him, she kills the child. However Abbie's greed seems to be the most compelling force in the play that drives her to marry Ephraim, seduce Eben and eventually kill the child. Desire Under the Elms is a play of infanticide based on greed for property, a mismatched marriage of a older man to a younger woman, lust, and misled impulsive behavior of a young man and woman. O'Neill's this work probably arises from his unsteady youth years. His acquaintance of all kinds of women of easy virtue probably caused him to create Abbie, a woman with low moral standards trying to achieve her ambitions through deceit.

Edward Albee's The American Dream deals with a family that dreamed of having a perfect child. The perfect child meant the one who would have the perfect American ideals. However their dreams are shattered when the child does not turn out what they had expected. The only solution they see is to mutilate the child. It is their insanity which leads Mommy and Daddy to kill the child. Mommy and Daddy call upon Mrs. Barker who works for the adoption agency only to ask for a refund. Hence what counts for them is only money. The family in the play seems to represent a disintegrated family. There is a lack of communication and a lack of understanding between the family members. This leads them to create a human being capable of keeping their dreams alive. Later in the play a young man appears which represents the typical "American Dream". The American Dream is a rebellion against the wealthy parents who adopted him and expected him to confirm to standards which they thought are expected from an ideal american child. The destruction of the child is probably in his mind parallel to the destruction of what he thought was his natural personality.

The title Buried Child itself sounds very distressing. A tragic incident has shaken the foundation of the family. A child was born out of the act of incest, so the patriarch Dodge who could not live with the shame kills the child by drowning it. The members of the family had been hiding the secret from the outside world. As in the play The American Dream, Dodge and Halie's communication is not only minimal but also incoherent. Though in her mid-sixties, Halie is not a submissive wife who keeps her sexuality under wraps. Her indulgence in a sexual relation with her son and then with father Dewis, a hypocritical clergyman, would among other things, help to thwart the possibility of incest. Elaine Tyler May has pointed out:

Presumably, these sexually fulfilled and appropriately submissive wives would lavish care on their children and sexual affection on their husbands. Sexually frustrated mothers whose husbands were not in command might turn their perverted desires towards their sons. (97)

The Buried Child is probably about the ills Shepard saw in the rural society and Dodge in his state probably represents the directionless and helplessness which he saw in his own father.

Carole Boyce Davies describes Toni Morrison's Beloved as, one of the most deliberate problematizings of motherhood that I have encountered. (125) Motherhood posed a problematic challenge to African American women under the slave regime. The situation, which did not allow the mothers the opportunity and freedom to nurture their children or perform the biological role as caregivers and mothers to their children and especially female children, had very debilitating consequences on the psyche of women. Patricia Collins argues that, "Black daughters raised by mothers grappling with hostile environment have to come to terms with their feelings about the difference between the idealized version of maternal love extent in popular culture and the strict and often troubled mothers in their lives." (127) Sethe, characterized throughout the book as an extremely loving and devoted mother, succeeds in killing only one of her children, her baby girl, by slitting the child's throat. Like Margaret Garner and the other slave women, the protagonist of the novel Beloved, Sethe, who is a mother, is unwilling to relinquish her children to the traumas of slave life and attempts to end their lives instead. Morrison born of black parents descendants of slaves had access to lots of folktales narrated by her father. The story of Beloved also come through accumulation of these stories especially the abuse of female slaves where a mother takes a difficult decision of eliminating her daughter to save her from a similar fate. 


\section{Conclusion}

All works have a prominent factor ruling over them,m none other than the murder of an infant who has simply no flaw within him but suffers at the hands of a man who is known as a social animal. Hence the main reasons behind all these infant murders have been studied above.

\section{References}

[1] Eliot, George. Adam Bede.(1859). New York: Signet Classics, 2004. Print Beer, Patricia. Reader, I Married Him: A Study of the Women Characters of Jane Austen, Charlotte Bronte, Elizabeth Gaskell and George Eliot. London: The Macmillan Press Ltd: 1974.Print.

[2] Haight, Gordon S. George Eliot: A Biography. New York: Oxford UP, 1968. Print.

[3] Henry, Nancy. The Cambridge Introduction to George Eliot. Cambridge: Cambridge UP, 2008

[4] Karpel, M.A. "Family Secrets." Family Process 19.1980.

[5] O’Neill, Eugene. "Desire Under the Elms." Masterpieces of the Drama. Trans. Richard Wilbur. Ed. D. Anthony English. 6th ed. New York: Macmillan, 1991. Print.

[6] Bogard, Travis. Contour in Time: The Plays of Eugene O’Neill. New York: Oxford University Press, 1988. Print.

[7] Goldman, Arnold. The Vanity of Personality: The Development of Eugene O’Neill. Modern Critical Views: Eugene O’Neill. Ed: Harold Bloom. New York: Chelsea House Publishers, 1987. Print.

[8] Albee, Edward. "The American Dream". The Collected Plays of Edward Albee:1958-65. Vol 1. Woodstock, New York, London: Overlook Duckworth, 2004. Print

[9] Bigsby, C.W.E. Albee. New York: Chips Bookshop Better Alert than Numb: Albee Since the Eighties. Bottoms, New York: Chips Bookshop. Cambridge. 1969. Print

[10] Bottoms, Stephen, ed. The Cambridge Companion to Edward Albee. Cambridge: Cambridge UP, 2005. Print

[11] Shepard, Sam. Buried Child. American Theatre. Vol.3, 1996. Print.

[12] Kerr, Walter. "Dreams Might Ring True But They're Not Real.” Washington Post 5 February 1961: G3. Proquest Historical Newspapers. UMI. University of Arizona Library.

[13] May, Elaine Tyler. Homeward Bound: American Families in the Cold War Era. New York: Basic Books, 1988. Print.

[14] Morrison, Toni. Beloved. New York: Knopf, 1987. Print.

[15] Davies, Carole Boyce. Black Women, Writing and Identity: Migrations of the Subject. New York: Routledge, 1994. Print.

[16] Collins, Patricia Hill. Black Feminist Thought: Knowledge, Consciousness and the Politics of Empowerment. New York: Harper, 1990. Print. 